\title{
MODEL PEMBELAJARAN CONCEPT ATTAINMENT DALAM MENINGKATKAN PEMAHAMAN KONSEP MATEMATIKA
}

\author{
Dini Palupi Putri \\ Sekolah Tinggi Agama Islam Negeri (STAIN) Curup \\ dinigusnadi@gmail.com
}

\begin{abstract}
ABSTRAK
Penelitian ini berawal dari rendahnya penguasaan siswa terhadap konsep-konsep matematika danmateri matematika sering dipahami dengan keliru oleh siswa. Tujuan penelitian ini adalah untuk mengetahui seberapa jauh peningkatan Pemahaman Konsep Matematika siswa kelas V SD Negeri 05 Curup Selatan setelah diterapkan model pembelajaran Concept Attainment.Jenis penelitian yang digunakan adalah Penelitian tindakan kelas yang terdiri dari 3 siklus, dimana setiap siklus terdiri dari empat tahapan yaitu perencanaan, tindakan, observasi dan refleksi. Teknik pengumpulan data melalui observasi dan tes evaluasi. Teknik analisis data melalui pengelolahan data hasil tes ketuntasan klasikal hasil belajar, pengolahan data hasil belajar, dan pengelolahan data hasil tes observasi. Hasil dari pengamatan aktifitas guru dan siswa mengalami peningkatan dari siklus ke siklus yaitu dari kategori cukup di siklus I, kategori cukup di siklus II, dan kategori baik di siklus III. Hasil penelitian tes pemahaman konsep pada siklus I, siklus II dan siklus III berturut-turut menunjukkan ketuntasan belajar klasikal siswa $61,11 \%, 70,08 \%$ dan $83,04 \%$. Peningkatan hasil tes dan lembar observasi pemahaman konsep dari siklus I kesiklus III, dapat disimpulkan bahwa penerapan Concept Attainment dapat meningkatkan pemahaman konsep Matematika siswa kelas $\mathrm{V}$ pada mata pelajaran matematika
\end{abstract}

Kata Kunci: Concept Attainment, Pemahaman Konsep Matematika, Matematika

\section{ABSTRACT}

This study originated from the lack of student mastery of the math concepts and math materials often mistakenly understood by students. The purpose of this study was to determine how far an increase understanding of Mathematics Concepts fifth grade students of SD Negeri 05 South Curup after applied learning model Concept Attainment. This type of research is a classroom action research that consisted of 3 cycles, each cycle consisting of four stages namely planning, action, observation and reflection. The 
technique of collecting data through observation and evaluation tests. Data analysis techniques through test data pengelolahan classical completeness learning outcomes, pengelolahan learning outcomes data, and test data processing observation. The results of observations of the activities of teachers and students has increased from cycle to cycle, namely from the category enough in the first cycle, the category enough in the second cycle, and both categories at the third cycle. The results of the study test understanding of the concept in the first cycle, the second cycle and the third cycle in a row shows the classical learning completeness students $61.11 \%$, $70.08 \%$ and $83.04 \%$. Improved results of tests and observation sheet understanding of the concept of the first cycle to the third cycle, it can be concluded that the application of the Concept Attainment can improve the understanding of mathematical concepts fifth grade students in mathematics

Keywords: Concept Attainment, Concept Training Mathematics, Mathematics

\section{PENDAHULUAN}

Penguasaan peserta didik terhadap materi konsep-konsep matematika masih rendah, penyebab rendahnya pemahaman konsep secara umum menurut Lynch dan Waters dalam Suarman (2007) adalah (1) siswa sering belajar dengan cara menghafal tanpa membentuk pengertian terhadap materi yang dipelajari. (2) materi pelajaran yang diajarkan memiliki konsep mengembang, sehingga siswa tidak dapat menemukan kunci untuk mengerti materi yang dipelajari. (3) pendidik mungkin kurang berhasil dalam menyampaikan kunci terhadap penguasaan konsep materi pelajaran yang sedang diajarkan. Padahal pemahaman konsep merupakan bagian yang paling penting dalam tujuan pembelajaran matematika artinya dalam mempelajari matematika peserta didik harus memahami konsep matematika terlebih dahulu agar dapat menyelesaikan soal-soal dan mampu mengaplikasikan pembelajaran tersebut ke dalam kehidupan sehari-hari. Salah satu upaya untuk mengatasi permasalahan tersebut, guru dituntut untuk profesional dalam merencanakan dan melaksanakan pembelajaran.

Rendahnya hasil belajar matematika siswa disebabkan oleh rendahnya tingkat pemahaman siswa pada konsep-konsep matematika. Puspendik 
Putri, D., P. MODEL PEMBELAJARAN CONCEPT ATTAINMENT DALAM MENINGKATKAN PEMAHAMAN

KONSEP MATEMATIKA. JURNAL TATSQIF. 15(1). Retrieved from http://ejurnal.iainmataram.ac.id/index.php/tatsqif/article/view/1319

(2015) Hasil TIMSS 2015 , tentang diagnosa hasil untuk perbaikan mutu dan peningkatan capaian, pencapaian skor matematika siswa Indonesia pada tahun 2015 yang populasinya kelas 4 SD/MI menduduki peringkat 45 dari 50 peserta. Siswa Indonesia perlu peningkatan kemampuan mengintegrasikan informasi, menarik kesimpulan serta mengeneralisir pengetahuan yang dimiliki ke hal-hal yang lain. Faktor lain yang mempengaruhi rendahnya tingkat pemahaman siswa antara lain, pembelajaran yang terlaksana cenderung berpusat pada guru, guru memberikan rumus-rumus dan memberi contoh soal dan penyelesaian. Kegiatan siswa hanya mengerjakan soal berdasarkan rumus yang ada dan berdasarkan contoh yang pernah diberikan oleh guru tanpa mengetahui dari mana datangnya rumus, siswa tidak dilibatkan dalam proses pemahaman konsep dan penemuan rumus, melainkan rumus langsung diberikan oleh guru. Siswa tidak diberi kesempatan untuk berkreasi dan mengemukankan ide-idenya. Dengan pembelajaran yang berpusat pada guru pemahaman terhadap konsep matematika tidak berkembang, siswa tidak kreatif dan kesulitan dalam memecahkan masalah, dan siswa menggolongkan matematika sebagai pelajaran yang tidak menyenangkan.

Sebagai solusi dari permasalahan rendahnya pemahaman konsep pada mata pelajaran matematika adalah adanya suatu model pembelajaran yang tepat yang dapat meningkatkan pemahaman konsep pada mata pelajaran matematika. Model pembelajaran Concept Attainment merupakan salah satu alternatif untuk dapat meningkatkan pemahaman konsep siswa.

Menurut Dadang (2015: 212), model pembelajaran Concept Attainment merupakan model pembelajaran proses mencari dan mendaftar sifat-sifat yang dapat digunakan untuk membedakan contoh-contoh yang tepat dengan contoh-contoh yang tidak tepat dari berbagai kategori. Pencapaian konsep itu juga harus dijelaskan dan diilustrasikan bagaimana model pencapaian konsep itu berlangsung. Siswa dibimbing dalam proses itu serta mengartikan pemikiran-pemikiran mereka Model pembelajaran pencapaian konsep adalah 
Putri, D., P. MODEL PEMBELAJARAN CONCEPT ATTAINMENT DALAM MENINGKATKAN PEMAHAMAN KONSEP MATEMATIKA. JURNAL TATSQIF. 15(1). Retrieved from http://ejurnal.iainmataram.ac.id/index.php/tatsqif/article/view/1319

suatu model pembelajaran yang menekankan pada pemahaman konsep kepada siswa, guru mengawali pengajaran dengan menyajikan data atau contoh dan yang bukan contoh, kemudian guru meminta siswa untuk mengamati data atau contoh tersebut dan siswa dibimbing agar mampu mengidentifikasi ciri-ciri atau karakteristik dari contoh yang diberikan.Ada dua hal penting dalam pembelajaran yang menggunakan model pembelajaran pencapaian konsep yaitu menentukan tingkat pencapaian konsep dan analisis data.

\section{Model Pembelajaran Concept Attainment}

Concept Attainment adalah model pembelajaran yang dirancang untuk menata atau menyusun data sehingga konsep-konsep penting dapat dipelajari secara tepat dan efisien. Model pembelajaran ini memiliki pandangan bahwa para siswa tidak hanya dituntut untuk mampu membentuk konsep melalui proses mengklafikasi data akan tetapi mereka juga dapat membentuk susunan konsep dengan kemampuannya sendiri.

Menurut Dadang (2015 :213), Pembentukan konsep, yang dasarnya dari model induktif yang telah dideskripsikan sebelumnya, merupakan proses yang mengharuskan siswa menentukan fondasi dasar saat mereka akan melakukan kategorisasi, maka pencapaian konsep mengharuskan mereka menggambarkan sifat-sifat dari suatu kategori yang sudah terbentuk dalam pikiran orang lain dengan cara membandingkan dan membedakan contohcontoh (disebut exemplars/contoh positif) yang berisi karateristikkarateristik itu dengan contoh-contoh yang tidak berisi karateristik ini (disebut contoh positif/contoh negatif).

Penggunaan model pembelajaran Concept Attainment diawali dengan pemberian contoh-contoh aplikasi konsep yang akan diajarkan, kemudian dengan mengamati contoh-contoh dan menurunkan definisi dari konsepkonsep tersebut. Hal yang paling utama yang mesti diperhatikan oleh seorang guru dalam penggunaan model pembelajaran ini adalah pemilihan contoh 
Putri, D., P. MODEL PEMBELAJARAN CONCEPT ATTAINMENT DALAM MENINGKATKAN PEMAHAMAN KONSEP MATEMATIKA. JURNAL TATSQIF. 15(1). Retrieved from http://ejurnal.iainmataram.ac.id/index.php/tatsqif/article/view/1319

yang tepat untuk konsep yang diajarkan, yaitu contoh tentang hal-hal yang akrab dengan siswa.

Pada prinsipnya, model pembelajaran Concept Attainment adalah suatu strategi mengajar yang menggunakan data untuk mengajarkan konsep kepada siswa, dimana guru mengawali pengajaran dengan cara menyajikan data atau contoh, kemudian guru meminta kepada siswa untuk mengamati data atau contoh tersebut. Atas dasar pengamatan ini akan terbentuk abstraksi. Model pembelajaran Concept Attainmentini dapat membantu siswa pada semua tingkatan usia dalam memahami tentang konsep dan latihan pengujian hipotesis.

Ada dua peran pokok guru dalam pembelajaran model pencapaian konsep yang perlu diperhatikan, adalah :

1. Menciptakan suatu lingkungan sedemikian hingga siswa merasa bebas untuk berpikir dan menduga tanpa rasa takut dari kritikan atau ejekan.

2. Menjelaskan dan mengilustrasikan bagaimana model pencapaian konsep itu seharusnya berlangsung, membimbing siswa dalam proses itu, membantu siswa menyatakan dan menganalisis hipotesis, dan mengartikulasi pemikiran-pemikiran mereka.

Aunnurrahman (2012: 158) menyatakan bahwa dalam pembelajaran, model pencapaian konsep untuk membangun sebuah konsep maka diharapkan siswa dapat mengingat kembali konsep sebelumnya yang telah dipelajari sebelumnya serta dapat membangun sebuah keterkaitan antara konsep yang baru dengan konsep sebelumnya. Guru juga menyajikan contohcontoh tambahan seperlunya.Ada tiga tugas penting yang harus diperhatikan guru selama aktivitas pencapaian konsep, yaitu mencatat, menguji, dan menyajikan data tambahan.

Berdasarkan defenisi-defenisi diatas dapat dipahami bahwa Model pembelajaran Concept Attainment merupakan suatu model pembelajaran yang efisien untuk mempresentasikan informasi yang telah terorganisir dari suatu topik yang luas menjadi topik yang lebih mdah dipahami untuk tingkatan 
perkembangan konsep. Model pembelajaran Concept Attainment ini dapat memberikan suatu cara menyampaikan konsep dan mengklafikasi konsepkonsep melatih siswa menjadi efektif dari pengembangan konsep.

Menurut Andrew (1997) langkah-langkah Concept Attainment adalah sebagai berikut:

1. Pastikan kita mempunyai 10 contoh soal benar dan 10 contoh salah sebelum memulai pembelajaran.

2. Tampilkan contoh benar dulu secara jelas.

3. Lanjutkan penampilan 2 atau lebih pada contoh-contoh banar dan contohcontoh salah.

4. Setelah 6 sampai 8 contoh, tes lisan kepada para siswa untuk menentukan contoh berikutnya benar atau salah.

5. Lanjutkan dengan 3 atau 4 contoh yang lain, jika siswa tidak yakin dengan jawabannya letakkan pada kegiatan netral.

6. Setelah sekitar 6 contoh-contoh benar, tanyakan kepada siswa "Apa ciriciri dari contoh yang benar?". Daftarkan ciri-ciri tersebut dimana para siswa dapat melihatnya. Daftar komentar siswa meskipun salah sekalipun.

7. Tes kembali ciri-ciri tersebut dengan contoh-contoh yang lain dan proses kembali contoh-contoh yang telah netral. Kemudian revisi kembali ciri-ciri tersebut dan buanglah ciri-ciri yang tidak penting.

8. Namailah konsep tersebut.

9. Hubungkanlah konsep tersebut dengan sifat-sifat atau ciri-ciri dengan memuat aturan.

10. Siswa menambah identitas dengan label "ya" dan "tidak" pada contohcontoh.

11. Siswa menggeneralisasikan contoh-contoh dari konsep tersebut.

12. Siswa menganalisa pemikiran mereka sendiri dengan memberi pertanyaan, misal ; Apakah ada yang berubah pendapatnya? 
Langkah-langkah tersebut akan lebih baik jika dikolaborasikan dengan model-model pembelajaran konstekstual, sehingga peningkatan kompetensi lebih matang baik dalam pemahaman konsep maupun pemecahan masalah.

Penerapan model pembelajaran pencapaian konsep dalam pembelajaran meliputi tiga tahapan pokok (Joyce Bruce, 2009: 136) :

1. Presentasi data dan identifikasi konsep, yaitu meliputi kegiatan

a. Guru menyajikan contoh-contoh yang telah dilabeli

b. Siswa membandingkan ciri-ciri positif dan negatif dari contoh yag dikemukakan

c. Siswa menyimpulkan dan menguji hipotesis

d. Siswa memberikan arti sesuai dengan ciri-ciri esensial

2. Menguji pencapaian konsep yang meliputi beberapa kegiatan

a. Siswa mengidentifikasi tambahan contoh yang tidak dilabeli

b. Guru mengkonfirmasikan hipotesis, konsep nama dan defenisi sesuai dengan ciri-ciri esensial

c. Siswa membuat contoh-contoh

3. Menganalisa kemampuan berfikir strategis yang meliputi:

a. Siswa mendeskripsikan pemikiran-pemikiran mereka

b. Siswa mendiskusikan hipotesis dan atribut-atribut

c. Siswa mendiskusikan bentuk dan jumlah hipotesis

Kelebihan dan kekurangan model pembelajaran Concept Attainment yang dikemukakan Rino (2014:12). Kelebihan model Concept Attainment, sebagai berikut:

1. Guru langsung memberikan presentasi informasi-informasi yang akan memberikan ilustrasi-ilustrasi tentang topik yang kan diajari oleh siswa, sehingga siswa mempunyai parameter dalam pencapaian tujuan pembelajaran.

2. Concept Attainment melatih konsep siswa, menghubungkan pada kerangka yang ada, dan menghasilkan pemahaman materi yang lebih mendalam 
Putri, D., P. MODEL PEMBELAJARAN CONCEPT ATTAINMENT DALAM MENINGKATKAN PEMAHAMAN KONSEP MATEMATIKA. JURNAL TATSQIF. 15(1). Retrieved from http://ejurnal.iainmataram.ac.id/index.php/tatsqif/article/view/1319

3. Concept Attainmentmeningkatkan pemahaman konsep matematika siswa Adapun Kekurangan model Concept Attainment adalah sebgai berikut:

1. Siswa yang memiliki kemampuan pemahaman rendah akan kesulitan untuk mengikuti pembelajaran, karena siswa akan diarahkan untuk menyelesaikan masalah-masalah yang diajukan.

2. Tingkat keberhasilan pembelajaran ditentukan oleh penyaian data yang disajikan oleh guru.

\section{Pemahaman Konsep Matematika Siswa}

Pemahaman konsep terdiri atas dua pengertian. Pertama,merupakan kelanjutan dari pembelajaran pemahaman konsep dalam satu pertemuan. Kedua,pembelajaran pemahaman konsep dilakukan pada pertemuan yang berbeda, tetapi masih merupakan lanjutan pemahaman konsep. Seperti yang diungkapkan oleh Purwanto (2004: 80):Pemahaman adalah tingkat kemampuan yangmengharapkan siswa mampu memahami arti atau konsep, situasi serta fakta yang diketahuinya.

Setiap materi pembelajaran matematika berisi sejumlah konsep yang harus disukai siswa. Pemahaman konsep sangat penting, karena dengan penguasaan konsep akan memudahkan siswa dalam mempelajari matematika. Pada setiap pembelajaran diusahakan lebih ditekankan pada penguasaan konsep agar siswa memiliki bekal dasar yang baik untuk mencapai kemampuan dasar yang lain seperti penalaran, komunikasi, koneksi dan pemecahan masalah.

Menurut Bruner dalam Herman (1990:48) ada beberapa tingkatan penguasaan konsep dalam matematika, yaitu sebagai berikut:

1. Nama yaitu mengucapkan konsep dengan tepat dan benar

2. Contoh-contoh yaitu menjelaskan konsep dengan kalimat dan kata-kata biasa, sehingga dapat dipahami oleh orang lain

3. Karakteristik yaitu mengidentifikasi ciri-ciri dari suatu konsep

4. Rentangan karakteristik yaitu menginterpretasikan suatu konsep 
5. Kaidah yaitu menerapkan konsep dengan benar dalam matematika ataupun dalam penerapan matematika diluar bidang matematika.

Menurut Hamalik dalam Usman (2006:33), untuk mengetahui apakah siswa telah mengetahui dan memahami suatu konsep, paling tidakada 4 hal yang telah diperbuatnya, yaitu sebagai berikut:

1. Ia dapat menyebutkan nama contoh-contoh konsep bila dia melihatnya

2. Ia dapat menyatakan ciri-ciri konsep itu

3. Ia dapat memilih, membedakan antara contoh-contoh dari yang bukan contoh

4. Ia mungkin lebih mampu memecahkan masalah yang berkenaan dengan konsep

Menurut Bloom dalam munir (2016:55) keampuan dan pemahaman terhadap konsep matematika dapat diihat dari kemampuan siswa dalam:

1. Kemampuan menyatakan ulang konsep yang telah dipelajari

2. Kemampuan memberikan contoh dari konsep yang telah dipelajari

3. Kemampuan mengklafikasikan objek-objek berdasarkan dipenuhi atau tidaknya persyaratan yang membentuk konsep tersebut

4. Kemampuan menyajikan konsep dalam berbagai macam bentuk representasi matematika

5. Kemampuan mengembangkan syarat perlu da syarat cukup suatu konsep

6. Kemampuan mengaitkan berbagai konsep matematika

7. Kemampuan menerapkan konsep secara algoritma.

Hamzah (2015: 61) Indikator untuk memahami konsep matematika adalah siswa mampu:

1. Menyatakan ulang sebuah konsep

2. Mengklasifikasi objek menurut tertentu sesuai dengan konsepnya

3. Memberikan contoh dan bukan contoh dari suatu konsep

4. Menyajikan konsep dalam berbagai bentuk representasi matematis

5. Mengembangkan syarat perlu atau syarat cukup dari suatu konsep 
Putri, D., P. MODEL PEMBELAJARAN CONCEPT ATTAINMENT DALAM MENINGKATKAN PEMAHAMAN

KONSEP MATEMATIKA. JURNAL TATSQIF. 15(1). Retrieved from http://ejurnal.iainmataram.ac.id/index.php/tatsqif/article/view/1319

6. Menggunakan dan memanfaatkan serta memilih prosedur atau operasi tertentu

7. Mengaplikasikan konsep atau algoritma dalam pemecahan masalah.

Penguasan konsep merupakan tingkatan hasil belajar siswa sehingga dapat mendefinisikan atau menjelaskan sebagian atau mendefinisikan bahan pelajaran dengan menggunakan kalimat sendiri. Dengan kemampuan siswa menjelaskan atau mendefinisikan, maka siswa tersebut telah memahami konsep atau prinsip dari suatu pelajaran meskipun penjelasan yang diberikan mempunyai susunan kalimat yang tidak sama dengan konsep yang diberikan tetapi maksudnya sama.

Berdasarkan uraian diatas, penulis dapat menyimpulkan,Pemahaman adalah suatu cara yang sistematis dalam memahami dan mengemukakan tentang sesuatu yang diperolehnya. Konsep yang bisa dicerna atau dipahami oleh peserta didik sehingga mereka mengerti apa yang dimaksudkan, mampu menemukan cara untuk mengungkapkan konsep tersebut. Jadi, Pemahaman Konsep adalah Kemampuan yang dimiliki seseorang dalam memahami, mengemukakan, mengelompokkkan kembali ilmu yang diperolehnya baik dalam bentuk lisan maupun tulisan kepada orang sehingga orang lain tersebut benar-benar mengerti apa yang disampaikan.

Dari tujuh indikator yang ada, peneliti menggunakan 3 indikator di terapkan dalam model pembelajaran Concept Attainment pada mata pelajaran matematika kelas V. Ada tiga indikator diantaranya adalah:

1. Kemampuan menyatakan ulang sebuah konsep adalah kemampuan siswa untuk mengungkapkan kembali apa yang telah dikomunikasikan kepadanya.

Contoh: Pada saat siswa belajar maka siswa mampu menyatakan ulang maksud dari pelajaran itu.

2. Kemampuan menggunakan, memanfaatkan dan memilih prosedur tertentu adalahkemampuan siswa menyelesaikan soal dengan tepat sesuai dengan prosedur. 
Contoh: Dalam belajar siswa harus mampu menyelesaikan soal dengan tepat sesuai dengan langkah-langkah yang benar.

3. Kemampuan mengklafikasikan konsep atau algoritma ke pemecahan masalah adalah kemampuan siswa menggunakan konsep serta prosedur dalam menyelesaikan soal yang berkaitan dengan kehidupan sehari-hari. Contoh: Dalam belajar siswa mampu menggunakan suatu konsep untuk memecahkanmasalah.

\section{METODOLOGI PENELITIAN}

Jenis penelitian ini adalah penelitian tindakan kelas (PTK), dan menggunakan model pembelajaran Concept Attainment. Model PTK yang digunakan adalah Model PTK Kurt Lewin dilakukan dengan beberapa siklus, setiap siklus terdiri dari 4 tahan yaitu: 1) Perencanaan (Planning), 2) Pelaksanaan Tindakan (Action), 3) Observasi (Observation), 4) Refleksi (Reflection). Teknik pengumpulan data dalam penelitian ini menggunakan hasil tes per siklus dan lembar observasi Guru dan siswa. Data Hasil tes di analisis dengan melihat ketuntasan belajar klasikal siswa, siswa dikatakan tuntas jika $80 \%$ siswa mendapatkan nilai lebih dari 65 . Sedangkan data hasil observasi guru dan siswa dianalisis dengan skor aktifitas guru dan siswa mendapat skor 40-64 dengan kriteria baik.

\section{HASIL DAN PEMBAHASAN}

Penerapan Model Concept Attainment dalam Meningkatkan Pemahaman

\section{Konsep Matematika}

\section{Siklus I}

\section{a. Perencanaan}

1) Guru menyiapkan bahan ajar berupa silabus dan RPP Sesuai dengan langkah-langkah pembelajaran dengan model Concept Attainment.

2) Guru menyiapkan LKS sesuai dengan langkah-langkah pembelajaran Concept ttainment. 
3) Guru menyiapkan kisi-kisi soal tes dan soal tes per siklus, kemudian memvalidasi soal tes kepada 2 orang dosen dan 1 orang guru.

4) Guru menyiapkan kisi-kisi lembar observasi Guru dan siswa, kemudian memvalidasi kepada validator.

\section{b. Tahap Pelaksanaan(Action)}

Pertemuan siklus 1 berisi penyampaian materi operasi hitung campuran dan dilajutkan dengan pemberian latihan secara individual, semua dilakan melalui model pembelajaran Concept Attainment sebagai berikut:

1) Sebelum melaksanakan proses pembelajaran yang dilaksanakan sesuai dengan perencanaan pelaksaan pembelajaran (RPP) yang telah disusun untuk tindakan siklus I, guru menyampaikan tujuan pembelajaran dan menjelaskan model pembelajaran yang digunakan.

2) Tahap-tahap pembelajaran Concept Attainmentsebagai berikut:

a) Guru menetapkan materi, menjelaskan materi operasi hitung campuran.

b) Guru mempresentasikan contoh-contoh yang berlabel dan meminta siswa mendefenisikan, dan memberikan kesempatan siswa bertanya mengenai materi yang belum dimengerti.

c) Guru mengurutkan sesuai dengan prosedur, dan meminta siswa membandingkan.

d) Gurumengkonfirmasikan nama-nama konsep menurut sifatsifatnya.

e) Guru meminta siswa membuat contoh dan bukan contoh dari materi, serta memberikan nama konsep.

f) Guru menganalisis startegi berfikir siswa dan meminta siswa mengerjakan latihan sesuai dengan model pembelajaran yang ditentukan. 
g) Siswa mengikuti langkah-langkah yang sudah ditentukan dalam model pembelajaran Concept Attainment.

h) Penutup, Guru membimbing siswa merangkum dan menarik kesimpulan, selanjutnya memberikan PR sebagaitugas atau latihan.

\section{c. Tahap Pengamatan (Observation) Siklus I}

1) Dari pengamatan terhadap guru dalam pengelolahan pemebelajaran Concept Attainment, diperoleh temuan sebagai berikut:

a) Pada tahap pendahuluan guru dapat mengkondisikan kelas dengan cukup baik, tujuan pembelajaran sudah disampaikan.

b) Tahap 1, Guru menetapkan materi, menjelaskan materi operasi hitung campuran. Disampaikan dengan suara keras dan cukup jelas, tetapi guru masih kesulitan memotivasikan siswa.

c) Tahap 2, Guru mempresentasikan contoh-contoh yang berlabel dan meminta siswa mendefenisikan, guru masih terlihat kesulitan dalam meminta siswa untuk mendefinisikan kembali materi yang disampaikan, karena masih ada siswa yang acuh dalam belajar.

d) Tahap 3, Guru mengurutkan sesuai dengan prosedur, dan meminta siswa membandingkan contoh dan bukan contoh, guru sudah cukup membimbing siswa dalam membandingkan contoh dan bukan contoh dari materi yang disampaikan.

e) Tahap 4, Guru mengkonfirmasikan nama-nama konsep menurut sifat-sifatnya,guru belum maksimal memfokuskan mengkonfirmasikan nama-nama konsep sehingga siswa belum memahami secara baik.

f) Tahap 5, Guru meminta siswa membuat contoh dan bukan contoh dari materi, serat memberikan nama konsep, guru sudah cukup baik membimbing siswa dalam pembuatan contoh dan bukan contoh serta meberikan konsep. 
g) Tahap 6, Guru menganalisis startegi berfikir siswa dan meminta siswa mengerjakan latihan sesuai dengan model pembelajaran yang ditentukan. Guru melakukan analisis cukup baik, tetapi pembahasan belum dilakukan secara nenyeluruh.

h) Tahap 7, siswa mengikuti langkah-langkah yang sudah ditentukan dalam model pembelajaran Concept Attainment.sudah cukup baik dilakukan.

i) Penutup, dalam pertemuan pertama siklus I guru tidak cukup waktu dalam membimbing siswa merangkum materi tetapi PR sudah diberikan. Untuk pertemuan berikutnya guru sudah cukup baik membimbing siswa dalam merangkum materi.

2) Dari pengamatan terhadap siswa diperoleh temuan sebagai berikut:

a) Siswa masih terkejut dan penasaran dengan apa yang dibawa oleh guru dalam kegiatan pembelajaran, tetapi masih ada beberapa siswa yang acuh tak acuh.

b) Beberapa siswa kurang memperhatikan dan kurang fokus terhadap materi yang dijelaskan guru.

c) Beberapa siswa masih belum paham dan masih kesulitan dalam membuat contoh dan bukan contoh serat memberikan nama konsep dari materi.

d) Masih ada beberapa siswa masih kesulitan dalam menganalisis strategi befikirnya dalam menemukan suatu konsep.

\section{d. Tahap Refleksi (Reflektion) Siklus I}

Setelah melaksanakan proses belajar mengajar dengan menerapkan model Pembelajaran Concept Attainment pada materi Operasi Hitung Campuran (penambahan dan pengurangan), pada akhir siklus I diadakan refleksi terhadap hasil-hasil yang telah diperoleh dari lembar observasi maupun tes siklus I. 
Pelakasanan observasi terhadap pembelajaran Matematika siklus I dilakukan oleh 2orang pengamat yaitu guru mata pelajaran Matematika yaitu Ibu Rosidah S.Pd, dan teman sejawat Ibu Sopiah, S.Pddengan mengisi lembar observasi aktivitas guru dan lembar observasi aktivitas siswa.

\section{1) Lembar Observasi Guru pada Siklus I}

Untuk menilai aktivitas guru selama pembelajaran berlangsung digunakan lembar observasi yang sesuai dengan model pembelaajran Concept Attainmentdalam pembelajaran Matematika (MM). Pengamat menerikan penilaian berdasarkan kriteria penilian lembar observasi pada aspek-aspek pengamatan yang terdiri dari 4 aspek penilaian aktivitas guru.

Nilai observasi aktivitas guru pada siklus I menurut pengamat I aktivitas guru pada siklus I adalah sebesar 34dan menurut pengamat II aktivitas guru pada siklus I adalah sebesar 34. Rata-rata nilai yang diperoleh adalah34. Hal ini menunujukkan aktivitas guru dalam menerapkan model pembelajaran Concept Attainment, dari data yang diperoleh dari 2 orang pengamat terhadap aktivitas guru diperoleh nilai rata-rata 34 yang termasuk kriteria cukup.

\section{2) Lembar Observasi Siswa pada Siklus I}

Untuk menilai aktivitas belajar siswa selama pembelajaran berlangsung digunakan lembar observasi yang sesuai dengan pembelajaran menggunakan model pembelajaran Concept Attainment.

Dari Dari data yang diperoleh dari 2 orang pengamat terhadap aktivitas siswa diperoleh nilai rata-rata 33 yang termasuk kriteria cukup.Dengan diperoleh kriteria cukup tersebut bahwa aktivitas siswa pada siklus I terdapat beberapa kekurangan yang perlu diperbaiki. 
Pada siklus pertama ini saat menerapkan model pembelajaran Concept Attainment, ada beberapa siswa masih lemah memahami materi sehingga pemahaman konsep Matematika pada materi operasi hitung campuran (penambahan dan pengurangan) masih tergolong lemah. Sehingga memerlukan waktu yang lebih banyak yaitu siklus ke II diterapkan kembali model pembelajaran Concept Attainment berulang kali sehingga dapat meningkatkan kualitas pembelajaran siswa pada mata pelajaran Matematika (MM). adapun hal-hal yang perlu diperbaiki pada siklus berikutnya, yaitu siswa harus lebih siap atau terfokus pada penjelasan guru, menerapkan langkah-langkah kerja yang diperintahkan, menganalis strategi berpikir mereka dalam menemukan kosep, memahami konsep atau materi pada lembar pada lembar kerja siswa (LKS).

\section{3) Hasil Tes Evaluasi Siklus I}

Dari hasil tes evaluasi 1 pada siklus 1 ini, siswa yang tuntas belajar diperoleh keterangan bahwa secara keseluruhan siswa kelas V SDN 05 Curup Selatan belum tuntas dengan kriteria ketuntasan minimal (KKM) sebesar 61,11\%. Secara individu sudah ada 11 orang siswa yang tuntas belajar dan yang belum tuntas sebanyak 7 orang. hal ini menunjukkan bahwa pembelajaran Matematika (MM) perlu dilakukan perbaikan untuk mencapai kualitas belajar secara keseluruhan di kelas V SDN 05 Curup Selatan dalam menerapkan model pembelajaran Concept Attainment.

\section{Siklus II}

Secara garis besar pelaksanaan siklus II berlangsung cukup baik, tetapi masih dalam penyampaian materi dengan bahasan sub pokok yang sama yaitu operasi hitung campuran. Secara teperinci prosedur penilitian tindakan kelas dalam siklus kedua diuraikan sebagai berikut:

\section{a. Perencanaan}


Agar kemampuan siswa dalam pemahaman konsep matematika dapat ditingkatkan dan hasil belajar siswa juga lebih meningkat, maka upaya perbaikan pada siklus berikutnya seperti dibawah ini :

1) Guru akan lebih mengoptimalkan dalam menjelaskan tentang model pembelajaran yang akan digunakan.

2) Guru harus menjelaskan dan memperesentasikan materi dengan perlahan-lahan atau secara bertahap agar siswa menyimak dan memahami materi yang disampaikan guru dengan model pembelajaran Concept Attainment.

3) Guru lebih mengoptilmalkan mengkonfirmasikan hipotesis, namanama, dan menyatakan kemabali defenisi menurut sifat-sifat pada materi yang diajarkan.

4) Guru lebih mengoptimalkan menganalaisis strategi berfikir siswa.

\section{b. Tahap Pelaksanaan (Action)}

Penyampaian materi operasi hitung campuran dan dilajutkan dengan pemberian latihan secara individual, semua dilakukan melalui model pembelajaran Concept Attainment sebagai berikut:

1) Sebelum melaksanakan proses pembelajaran yang dilaksanakan sesuai dengan perencanaan pelaksaan pembelajaran (RPP) yang telah disusun untuk tindakan siklus I, guru menyampaikan tujuan pembelajaran dan menjelaskan model pembelajaran yang digunakan.

2) Tahap-tahap pembelajaran Concept Attainment sebagai berikut:

a) Guru menetapkan materi, menjelaskan materi operasi hitung campuran.

b) Guru mempresentasikan contoh-contoh yang berlabel dan meminta siswa mendefenisikan, dan memberikan kesempatan siswa bertanya mengenai materi yang belum dimengerti.

c) Guru mengurutkan sesuai dengan prosedur, dan meminta siswa membandingkan. 
d) Gurumengkonfirmasikan nama-nama konsep menurut sifatsifatnya.

e) Guru meminta siswa membuat contoh dan bukan contoh dari materi, serta memberikan nama konsep.

f) Guru menganalisis startegi berfikir siswa dan meminta siswa mengerjakan latihan sesuai dengan model pembelajaran yang ditentukan.

g) Siswa mengikuti langkah-langkah yang sudah ditentukan dalam model pembelajaran Concept Attainment.

h) Penutup, guru membimbing siswa merangkum dan menarik kesimpulan.

\section{c. Tahap Pengamatan (Observation) Siklus II}

1) Dari pengamatan terhadap guru dalam pengelolahan pembelajaran Concept Attainment, diperoleh temuan sebagai berikut:

a) Pada tahap pendahuluan guru dapat mengkondisikan kelas dengan cukup baik, tujuan pembelajaran sudah disampaikan.

b) Guru menetapkan materi, menjelaskan materi operasi hitung campuran disampaikan dengan suara keras dan cukup jelas.

c) guru sudah cukup membimbing siswa dalam membandingkan contoh dan bukan contoh dari materi yang disampaikan.

d) Guru mengkonfirmasikan nama-nama konsep menurut sifatsifatnya, guru sudah maksimal memfokuskan mengkonfirmasikan nama-nama konsep, walapun masih ada beberapa siswa belum memahami secara baik.

e) Guru menganalisis startegi berfikir siswa dan meminta siswa mengerjakan latihan sesuai dengan model pembelajaran yang ditentukan. Guru melakukan analisis cukup baik.

2) Dari pengamatan terhadap siswa diperoleh temuan sebagai berikut:

a) Siswa sudah memahami model pembelajaran yang diterapkan dan mengikuti proses pembelajaran dengan baik. 
b) Beberapa siswa lebih memperhatikan dan fokus terhadap materi yang dijelaskan guru.

c) Beberapa siswa sudah paham dan walaupun masih ada siswa kesulitan dalam menganalisis strategi berfikir menemukan konsep, membuat contoh dan bukan contoh serta memberikan nama konsep dari materi.

\section{d. Tahap Refleksi Siklus II}

Pelaksanaan observasi terhadap pembelajaran siklus II dilakukan oleh 2 orang pengamat yaitu guru mata pelajaran Matematika (MM) dengan teman sejawat yaitu Ibu Rosidah, S.Pd, dan Ibu Sopiah, S.Pd. Dengan mengisi lembar observasi guru dan lembar observasi siswa. Lembar ini guna melihat bagaimana aktivitas guru dan siswa selama pembelajaran berlangsung dengan menggunakan model pembelajaran Concept Attainment.

\section{1) Lembar Observasi Guru pada Siklus II}

Untuk menilai aktivitas guru selama pembelajaran berlangsung digunakan lembar observasi yang sesuai dengan model pembelajaran Concept Attainmentdalam pembelajaran Matematika (MM). Pengamat memberikan penilaian berdasarkan kriteria penilaian lembar observasi pada aspek-aspek pengamatan yang terdiri dari 17 aspek penilaian aktivitas guru.

Nilai observasi aktivitas guru pada siklus I menurut pengamat I aktivitas guru pada siklus II adalah sebesar 47 menurut pengamat II aktivitas guru pada siklus II adalah sebesar 47. Rata-rata nilai yang diperoleh adalah 47. Hal ini menunujukkan aktivitas guru dalam menerapkan model pembelajaran Concept Attainment sub pokok bahsan yaitu operasi hitung campuran (Perkalian dan Pembagian) termasuk dalam kriteria baik.

\section{2) Lembar Observasi Siswa pada Siklus II}


Untuk menilai aktivitas belajar siswa selama pembelajaran berlangsung digunakan lembar observasi yang sesuai dengan pembelajaran menggunakan model pembelajaran Concept Attainment.

Nilai observasi aktivitas siswa pada siklus II menurut pengamat I aktivitas siswa pada siklus II adalah sebesar 53. Menurut pengamat II aktivitas guru pada siklus II adalah sebesar 51. Rata-rata nilai yang diperoleh adalah 52. Hal ini menunujukkan aktivitas guru dalam menerapkan model pembelajaran Concept Attainment sub pokok bahasan yaitu operasi hitung campuran (perkalian dan pembagian) termasuk dalam kriteria baik.

\section{3) Hasil Tes Evaluasi pada siklus II}

Dari hasil tes evaluasi 2 pada siklus 2 ini, siswa yang tuntas belajar diperoleh keterangan bahwa pada tahap siklus II kelas V SDN 05 Curup Selatan tuntas belajar secara keseluruhan dengan kriteria ketuntsan belajar 88,88\%.Tingkat keberhasilan pada pemahaman konsep sangat tinggi, meskipunada 2orang siswayang belum tuntas belajar. Dengan kriteria ketuntasan minimal (KKM) sebesar 60. Hal ini menunjukkan bahwa penerapan model pembelajaran Concept Attainment meningkatkan pemahaman konsep pada mata pelajaran Matematika materi Operasi Hitung Campuran. Proses pembelajaran pada siklus II sudah meningkat dari hasil belajar sebelumnya dan juga ketuntasan belajar kalsikal sudah memenuhi standaryang dikemukakan Depdiknas 2006 yaitu dikatakan tuntas apabila ketuntasan klasikal maksimal sudah mencapai $85 \%$.

\section{Siklus III}

Secara garis besar pelaksanaan siklus III berlangsung cukup baik, tetapi masih dalam penyampaian materi dengan bahasan sub pokok yang 
sama yaitu operasi hitung campuran. Secara teperinci prosedur penilitian tindakan kelas dalam siklus kedua diuraikan sebagai berikut:

\section{a. Perencanaan}

Agar kemampuan siswa dalam pemahaman konsep matematika dapat ditingkatkan dan hasil belajar siswa juga lebih meningkat, maka upaya perbaikan pada siklus berikutnya seperti dibawah ini :

1) Guru akan lebih mengoptimalkan dalam menjelaskan tentang model pembelajaran yang akan digunakan.

2) Guru harus menjelaskan dan memperesentasikan materi dengan perlahan-lahan atau secara bertahap agar siswa menyimak dan memahami materi yang disampaikan guru dengan model pembelajaran Concept Attainment.

3) Guru lebih mengoptilmalkan mengkonfirmasikan hipotesis, namanama, dan menyatakan kemabali defenisi menurut sifat-sifat pada materi yang diajarkan.

4) Guru lebih mengoptimalkan menganalaisis strategi berfikir siswa.

\section{b. Tahap Pelaksanaan (Action)}

Penyampaian materi operasi hitung campuran dan dilajutkan dengan pemberian latihan secara individual, semua dilakukan melalui model pembelajaran Concept Attainment sebagai berikut:

1) Sebelum melaksanakan proses pembelajaran yang dilaksanakan sesuai dengan perencanaan pelaksaan pembelajaran (RPP) yang telah disusun untuk tindakan siklus III, guru menyampaikan tujuan pembelajaran dan menjelaskan model pembelajaran yang digunakan.

2) Tahap-tahap pembelajaran Concept Attainment sebagai berikut:

a) Guru menetapkan materi, menjelaskan materi operasi hitung campuran. 
b) Guru mempresentasikan contoh-contoh yang berlabel dan meminta siswa mendefenisikan, dan memberikan kesempatan siswa bertanya mengenai materi yang belum dimengerti.

c) Guru mengurutkan sesuai dengan prosedur, dan meminta siswa membandingkan.

d) Gurumengkonfirmasikan nama-nama konsep menurut sifatsifatnya.

e) Guru meminta siswa membuat contoh dan bukan contoh dari materi, serta memberikan nama konsep.

f) Guru menganalisis startegi berfikir siswa dan meminta siswa mengerjakan latihan sesuai dengan model pembelajaran yang ditentukan.

g) Siswa mengikuti langkah-langkah yang sudah ditentukan dalam model pembelajaran Concept Attainment.

h) Penutup, guru membimbing siswa merangkum dan menarik kesimpulan.

\section{c. Tahap Pengamatan (Observation) Siklus III}

1) Dari pengamatan terhadap guru dalam pengelolahan pembelajaran Concept Attainment, diperoleh temuan sebagai berikut:

a) Pada tahap pendahuluan guru dapat mengkondisikan kelas dengan cukup baik, tujuan pembelajaran sudah disampaikan.

b) Guru menetapkan materi, menjelaskan materi operasi hitung campuran disampaikan dengan suara keras dan cukup jelas.

c) guru sudah cukup membimbing siswa dalam membandingkan contoh dan bukan contoh dari materi yang disampaikan.

d) Guru mengkonfirmasikan nama-nama konsep menurut sifatsifatnya, guru sudah maksimal memfokuskan mengkonfirmasikan nama-nama konsep, walapun masih ada beberapa siswa belum memahami secara baik. 
e) Guru menganalisis startegi berfikir siswa dan meminta siswa mengerjakan latihan sesuai dengan model pembelajaran yang ditentukan. Guru melakukan analisis cukup baik.

2) Dari pengamatan terhadap siswa diperoleh temuan sebagai berikut:

1. Siswa sudah memahami model pembelajaran yang diterapkan dan mengikuti proses pembelajaran dengan baik.

a) Beberapa siswa lebih memperhatikan dan fokus terhadap materi yang dijelaskan guru.

b) Beberapa siswa sudah paham dan walaupun masih ada siswa kesulitan dalam menganalisis strategi berfikir menemukan konsep, membuat contoh dan bukan contoh serta memberikan nama konsep dari materi.

\section{d. Tahap Refleksi Siklus III}

Pelaksanaan observasi terhadap pembelajaran siklus III dilakukan oleh 2 orang pengamat yaitu guru mata pelajaran Matematika (MM) dengan teman sejawat yaitu Ibu Rosidah, S.Pd, dan Ibu Sopiah, S.Pd. Dengan mengisi lembar observasi guru dan lembar observasi siswa. Lembar ini guna melihat bagaimana aktivitas guru dan siswa selama pembelajaran berlangsung dengan menggunakan model pembelajaran Concept Attainment.

\section{Perkembangan Hasil Observasi dan Tes Evaluasi}

\section{Observasi Aktivitas Siswa}

Aktivitas kegiatan pembelajaran siswa dapat dilihat dari hasil pengamatan atau observasi yang dilakukan pengamat. Aktivitas guru selama kegitan pembelajaran dengan kategori cukup-sangat baik dapat dilihat pada tabel 1 berikut: 
Tabel 1

Perkembangan Hasil Observasi Aktivitas Belajar Siswa

\begin{tabular}{|c|c|c|c|}
\hline No. & Siklus & Rata-rata Skor & Kriteria \\
\hline 1 & I & 33 & Cukup \\
\hline 2 & II & 52 & Baik \\
\hline 3 & III & 62 & Baik \\
\hline
\end{tabular}

Hasil pengamatan atau observasi yang disajikan pada tabel diatas, dapat dideskripsikan bahwa aktivitas siswa selama mengikuti pembelajaran selalu meningkatkan. Peningkatan aktivitas tersebut meningkatnya pemahaman konsep matematika dapat dilihat berdasarkan hasil observasi yang meliputi kegiatan-kegitan seperti: aktivitas mengikuti pelajaran, keaktifan siswa dalam mengikuti langkah atau prosedur pembelajaran dalam model Concept Attainment pelajaran Matematika.

\section{Observasi Aktivitas Guru}

Aktivitas kegiatan guru dapat dilihat dari hasil pengamatan atau observasi yang dilakukan pengamat atau peneliti. Aktivitas guru selama kegiatan pembelajaran dengan kategori cukup-baik dapat dilihat pada tabel 2 berikut:

\section{Tabel 2}

Perkembangan Hasil Observasi Aktivitas Guru

\begin{tabular}{|c|c|c|c|}
\hline No. & Siklus & Rata-rata Skor & Kriteria \\
\hline 1 & I & 34 & Cukup \\
\hline 2 & II & 47 & Baik \\
\hline 3 & III & 56 & Baik \\
\hline
\end{tabular}

Hasil pengamatan atau observasi yang disajikan pada tabel diatas, dapat dideskripsikan bahwa aktivitas guru kegiatan pembelajaran selalu meningkat. Peningkatan aktivitas tersebut dapat dilihat berdasarkan observasi yang meliputi kegiatan-kegiatan yang dilaksankan oleh guru ketika mengajar didalam kelas. 


\section{Perkembangan Hasil Tes Per Siklus Siswa}

Hasil tes evaluasi siswa per siklus dapat dilihat pada tabel 3 berikut:

Tabel 3

Hasil Tes Evaluasi Siswa Per Siklus

\begin{tabular}{|c|c|c|}
\hline No. & Siklus & Ketuntasan Klasikal \\
\hline 1 & I & $61.11 \%$ \\
\hline 2 & II & $70.08 \%$ \\
\hline 3 & III & $83.04 \%$ \\
\hline
\end{tabular}

Dari tabel 3 di atas dapat di tarik kesimpulan, hasil tes siswa dari siklus ke siklus terdapat peningkatan hasil belajar. Dengan ini dapat disimpulkan dengan menggunakan metode Concept Attainment dapat meningatkan kemampuan konsep siswa.

\section{PEMBAHASAN}

\section{Pemahaman Konsep Siswa sebelum Menerapkan Model Pembelajaran Concept Attainment}

Siswa diberikan soal pretest, untuk melihat kemampuan awal tentang konsep operasi hitung belajar. Dari 5 soal essay yang diberikan, hanya 7 orang siswa yang mencapai nilai KKM dari 18 jumlah siswa keseluruhan. Pada soal dengan indokator menyatakan ulang konsep, hanya 7 orang yang bisa menjawab, sisanya 11 orang menjawab soal tetapi kurang tepat. Pada indikator soal memberikan contoh dan non contoh hanya 13 orang yang enjawab soal dengan benar, sisanya 5 orang menjawab dengan jawaban yang kurang lengkap. Pada indikator menggunakan dan memanfaatkan serta memilih prosedur tertentu sebanyak 10 orang siswa menjawab soal dengan benar, sisanya 8 orang siswa menggunakan dan memanfaatkan prosedur tertentu menjawab soal dengan salah.

Ketuntasan belajar klasikal untuk mata pelajaran Matematika (MM) adalah70\% dan ketuntasan belajar secara individu adalah apabila siswa memperoleh nilai $\geq 65$, sedangkan hasil belajar siswa sebelum menerapkan 
Putri, D., P. MODEL PEMBELAJARAN CONCEPT ATTAINMENT DALAM MENINGKATKAN PEMAHAMAN

KONSEP MATEMATIKA. JURNAL TATSQIF. 15(1). Retrieved from http://ejurnal.iainmataram.ac.id/index.php/tatsqif/article/view/1319

model pembelajaran Concept Attainment yaitu dengan nilai rata-rata 56,94 dan prensentase ketuntasan belajar klasikal hanya 50\%. Dan dinyatakan belum memenuhi target. Disimpulkan bahwa tingkat pemahaman konsep matematika siswa kelas V sebelum menerapkan model Concept Attainment dinyatakan masih tergolong rendah.

\section{Penerapan Model Concept Attainment dalam Meningkatkan}

\section{Pemahaman Konsep Matematika}

Pada Penerapan model pembelajaran Concept Attainment, siswa dibagi dalam beberapa kelompok, awalnya siswa masih bingung dan belum bisa beradaptasi dengan pemberian model pembelajaran yang masih baru dikenalkan. Tetapi, setelah bebrapa kali pertemuan siswa sudah bisa beradaptasi. Pembelajaran dimulai dengan siswa dibagi dalam beberapa kelompok, dan dilanjutkan dengan guru membagikan LKS kepada seiap siswa, kemuadian siswa dibimbing dalam pemeblajaran untuk menyelesaikan LKS, kemudian siswa diminta untuk mempersentasikan hasil diskusi kelompok dan terakhir siswa diberi tugas per individu.

Siswa yang diberikan materi dengan menerapkan model Concept Attainment setelah proses belajar mengajar akan tahu saran yang akan dicapai sehingga dapat mengarahkan mereka dalam belajarnya. Dadang (2015:212) Concept Attainment model yang dirancang untuk menata atau menyusun data sehingga konsep-konsep penting dapat dipelajari, secara tepat dan efisien. Pada model ini siswa tidak hanya dituntut untuk mampu membentuk konsep melalui proses pengklafikasi data akan tetapi mereka juga dapat membentuk susunan konsep dengan kemampuannya sendiri.

a. Aktivitas Guru

Berdasarkan analisis hasil observasi guru pada siklus I, siklus II dan siklus III dalam pembelajaran Matematika menggunakan model pembelajaran Concept Attainment dapat terlihat aspek-aspek yang tercapai dan belum tercapai dalam pembelajaran. Pada siklus I ada 10 aspek yang telah tercapai dan 6 aspek yang belum mencapai skor 
sempurna. Pada siklus II aspek yang tercapai 12 dan 4 aspek yang belum mencapai skor sempurna. Secara keseluruhan aspek-aspek tersebut berkriteria "Cukup" dan sudah tercapai secara maksimal. Pada siklus III ada 14 aspek yang mencapai skor sempurna sehingga mencapai kriteria Baik.

Peningkatan ini terjadi karena kekurangan pada siklus I dan siklus II telah diperbaiki pada siklus III. Dengan adanya peningkatan rata-rata skor tersebut dapat diartikan bahwa guru dalam proses pembelajaran MM dapat meningkat menggunakan model Concept Attainment. Peningkatan ini sejalan dengan pendapat Bruner (1997). mengatakan Concept Attainment merupakan"proses mencari dan medaftar sifat-sifat yang digunakan untuk membedakan contohdanbukan contoh yang tepat dan tidak tepat. Sehingga dalam proses pembelajran MM menggunakan model pembelajaran Concept Attainmentdapat mengaktifkan proses pembelajaran dan aktivitas guru meningkat. Hal ini ditunjukkan dengan rata-rata skor aktivitas guru pada siklus I adalah 34, siklus II adalah 47 dan meningkat pada siklus III dengan nilai rata-rata skor 56 dalam kriteria cukup.

b. Aktivitas Siswa

Berdasarkan analisis observasi siswa pada siklus I, siklus II dan III menunjukkan bahwa pembelajaran MM menggunkan model pembelajaran Concept Attainmentdapat meningkatkan kualitas proses pembelajaran baik dari segi aktivitas guru ataupun aktivitas siswa pada mata pembelajaran MM kelas V SDN 05. Hal ini terlihat aspek-aspek yang telah tercapai dan belum tercapai dalam pembelajaran. Pada siklus I ada 10 aspek yang telah tercapai dan 3 aspek yang belum mencapai skor sempurna. Pada siklus II ada 13 aspek yang mencapai kriteria cukup. Pada siklus III hampir keselururuhan tercapai dengan maksimal. Secara keseluruhan aspek-aspek tersebut masuk dalam kriteria "Baik" 
Peningkatan aktivitas siswa pada siklus III ini terjadi peningkatan rata-rata skor menggunakan model Concept Attainment. Peningkatan ini terjadi karena kekurangan pada siklus I dan siklus II telah diperbaiki pada siklus III. Dengan adanya peningkatan rata-rata skor tersebut dapat diartikan bahwa aktivitas siswa dalam proses pembelajaran MM dapat meningkat menggunakan model pemebelajaran Concept Attainment.Dengan menggunakan model pembelajaran Concept Attainmentmaka proses pembelajaran akan menarik karena dikembangkan atas dasar teori-teori dan pengalaman nyata sehingga membangkitkan semangat belajar siswa secara optimal dengan memotivasi diri siswa sehingga didapatkan hasil belajar yang optimal. Hal ini ditunjukkan dengan nilai rata-rata skor aktivitas sisa pada siklus I adalah 33, siklus Iiadalah 52 dan meningkat pada siklus III dengan nilai rata-rata skor 62 dalam kriteria "baik".

Berdasarkan hasil pengamatan pada kegiatan pembelajaran diperoleh gambaran bahwa kemampuan guru dalam melaksanakan proses pembelajaran telah meningkat dan aktivitas siswa pun meningkat dalam pemebelajaran MM menggunkan model Concept Attainment. Sehingga pada penelitian ini proses pembelajaran MM menggunakan model pembelajaran Concept Attainment ini dapat meningkatkan kualitas proses pembelajaran MM disetiap siklusnya.

Model Concept Attainmentini cukup baik diterapkan, pada tahap siklus I beberapa siswa masih belum paham dan masih kesulitan dalam membuat contoh dan bukan contoh serta memberikan nama konsep dari materi, akan tetapi mereka mulai memperhatikan dengan fokus terhadap model yang diterapkan. Pada siklus II dalam penerapan model Concept Attainment siswa mulai sudah memahami model pembelajaran yang diterapkan dengan baik, pada saat guru meminta siswa untuk memberikan mereka mulai manganalisis strategi berfikir menemukan konsep, membuat contoh dan bukan contoh serta memberikan nama 
konsep dari materi.Pada siklus III siswa sudah mulai aktif dalam proses pembelajaran dan dari hasil tes evaluasi siswa sudah mencapai kriteria baik. Hal ini menunjukkan bahwa penerapan model pembelajaran Concept Attainment meningkatkan pemahaman konsep pada mata pelajaran Matematika materi Operasi Hitung Campuran.

\section{Pemahaman Kosep Matematika Siswa Kelas V SD Negeri 05 Curup} Selatan dapat Meningkat setelah diterapkannya Model Concept Attainment

Pemahaman konsep siswa pada siklus I pada tes pemahaman konsep ini terdapat 18 orang siswa yang mengikuti tes, pada siklus I terdiri dari 10 butir soal dan terdapat 3 indikator pencapaian pemahaman konsep yaitu, 1) Kemampuan menyatakan ulang konsep, 2) kemampuan menggunakan, memilih dan memanfaatkan prosedur tertentu dan 3) kemampuan memecahkan masalah. Pada siklus I, pemahaman konsep peserta didik untuk indikator menyatakan ulang konsep.

Data hasil pemahaman konsep siswa selama proses pembelajaran berlangsung diperoleh rata-rata hasil tes evaluasi pada silus I adalah 61,11\%, siklus II adalah 70.08\% dan siklus III 83.04\%, peningkatan hasil belajar siswa siklus I ke siklus III menunjukkan adanya peningkatan pemahaman konsep selama proses belajar berlangsung.

Adapun presentase ketuntasan hasil belajar siswa menunjukkan bahwa pada siklus I sebesar 61,11\% dan meningkat menjadi 83,04\% pada siklus III. Peningkatan pemahaman konsep pada hasil belajar siswa pada siklus II, menunjukkan antusias siswa dalam pelajaran matematika dengan penerapan model Concept Attainment.

Peningkatan presentase aktivitas siswa dari siklus I ke siklus II juga terlihat pada saat siswa mendengarkan penjelasan guru, mencatat/menyalin pelajaran, bertanya, menjawab/menanggapi pertanyaan, meminta bimbingan dari guru, menganalisa cara bekerja mereka dalam belajar, mengerjakan evaluasi. Hal ini membuktikan bahwa 
siswa memiliki perhatian yang besar dalam belajar, khususnya dalam pelajaran matematika yang menerapkan model Concept Attainment.Model Concept Attainment cukup baik diterapkan dalam pembelajaran pemberian latihan, observasi, tes evaluasi.

Penerapan Concept Attainmentakan memperdalam pengertian siswa, juga mampu meningkatkan pemahaman konsep terhadap pelajaran yang diterima, pada saat siswa belajar maka siswa mampu menyatakan ulang konsep maksud dari pelajaran itu, dalam belajar siswa mampu menggunakan konsep untuk memecahkan masalah, melatih anak berfikir kreatif, melatih siswa kearah belajar mandiri, dan melatih siswa untuk menemukan sendiri cara-cara yang tepat untuk menyelesaikan soal dengan tepat sesuai dengan langkah-langkah atau prosedur yang benar.

Hasil peningkatan pemahaman konsep dari hasil penelitian dengan menggunakan model Concept Attainmentjuga dapat dilihat dari dari kegiatan siklus I sampai pada kegiatan siklus II menunjukkan adanya peningkatan dalam hal proses pembelajaran (aktivitas guru dan aktivitas siswa). Hal ini dilihat dari analisis hasil data observasi terhadap guru dan analisis hasil data observasi terhadap aktivitas siswa pada proses pembelajaran siklus I dan siklus II.

Berdasarkan data yang sudah dianalisis, prestasi belajar diperoleh dari nilai tes yang telah dilaksanakan seluruh siswa dalam proses belajar mengajar. Prestasi belajar siswa dari kemampuannya dapat dilihat dari nilai rata-rata dan presentase ketuntasan belajar siswa sebelum menerapkan model pembelajaran Concept Attanment.

Dapat dilihat bahwa nilai rata-rata hasil belajar siswa sebelum menggunakan model pembelajaran Concept Attainment adalah 56,94dengan presentase ketuntasan 50\% dengan jumlah siswa tuntas sebanyak 18 orang siswa sedangkan yang belum tuntas sebanyak 9orang siswa. Hal ini masih kurang mencapai target $60 \%$. 
Dari penjelasan diatas terlihat bahwa pemahaman konsep matematika siswa tergolong rendah. Hasil belajar untuk pemahaman konsep akan diperbaiki dengan menggunakan Concept Attainmentyang mana dapat menambah minat siswa dalam belajar terutama dalam pelajaran Matematika. Nilai rata-rata setelah menerapkan model pembelajaran Concept Attainmentdapat dilihat pada lampiran. Dari tabel lampiran dapat dilihat bahwa nilai rata-rata hasil belajar siswa pada siklus I diperoleh rata-rata $65 \%$ dan nilai presentase pada siklus I adalah $61,11 \%$ dengan jumlah siswa yang tuntas adalah 18 orang siswa dan jumlah siswa yang belum tuntas sebanyak 8 orang siswa, dengan begitu hasil pada siklus I belum dapat mencapai target walaupun sudah ada peningkatan, jika dibandingkan dengan presentase ketuntasan belajar sebelum mengunakan model pembelajaran Concept Attainment yang diperoleh sebesar 50\%. Hal ini karena guru tidak menggunakan model pembelajaran yang berbeda dalam proses pembelajaran.

Pada siklus II hasil belajar siswa yang diperoleh seperti yang terlihat pada tabel lampiran 24 nilai rata-rata hasil belajar siswa mencapai 76dan nilai presentase ketuntasan belajar pada siklus II yaitu 88,88 \% dengan jumlah siswa yang tuntas sebanyak16 orang siswa, yang belum tuntas sebanyak 2 orang siswa. Bila dibandingkan dengan hasil yang diperoleh pada siklus I terdapat kenaikan prsentasi belajar siswa. Peningkatan hasil belajar siswa terjadi karena guru telah memperbaiki kelemahan pada proses mengajar pada siklus sebelumnya. Peningkatan hasil belajar telah menunjukkan bahwa adanya peningkatan pemahaman konsep siswa pada proses belajar berlangsung. Guru telah berusaha optimal dalam memberikan susana baru dalam proses pembelajaran yaitu dengan menerapkan model pembelajaran Concept Attainment sehingga siswa dapat meningkatkan pemahaman konsep dengan hasil belajar siswa meskipun masih ada beberapa siswa yang belum tuntas. 
Dilihat pada diagram peningkatan pencapaian pemahaman konsep hal ini membuktikan bahwa dengan menggunakan model Concept Attainmentdapat meningkatkan pemahaman konsep siswa dalam mata pelajaran Matematika, serta dapatmembantu guru dalam meningkat aktivitas belajar mengajar guru dan siswa dalam pelajaran Matematika, dengan susana belajar yang berbeda siswa lebih aktif dan menarik sehingga siswa tidak cepat bosan dan jenuh selama proses belajar berlangsung. Concept Attainmentdalam mata pelajaran Matematika dapat meningkatkan pemahaman konsep siswa di kelas V SDN 05 Curup Selatan.

Berdasarkan hasil penelitian yang sudah dilakukan, hasil akhir dari penelitian yang telah dilaksanakan sebanyak 2 siklus pada mata pelajaran MM di Kelas V SDN 05 Curup Selatan, terdapat peningkatan yaitu:Peningkatan pemahaman konsep terebut terjadi karena proses pembelajaran di siklus II mengacu pada refleksi proses pembelajaran siklus II. Kelemahan dan kekurangan pembelajaran yang ditemui pada siklus I yang diperbaiki pada proses pembelajaran siklus II sesuai denga langkahlangkah yang telah direncanakan. Dalam hal ini proses pembelajaran yang telah dilakukan dengan menggunkan model pembelajaran Concept Attainmnetdapat mencapai tujuan yang diinginkan yaitu nilai ketuntasan dalam pemebelajaran dapat dicapai (Presentase ketuntasan pembelajaran mengalami peningkatan). Artinya proses pembelajaran pemahaman konsep matematika dengan menggunkan model pembelajaran Concept Attainment dapat digunakan untuk mencapai tujuan pembelajaran yang diinginkan.

Peningkatan didapatkan sudah mencapaitingkat ketuntasan belajar yang kalisikal. Karena menurut sekolah tersebut bahwa ketuntasan belajar klasikal telah tercapai apabila dalam kelas tersebut sudah mencapai 70\% dari jumlah siswa yang mendapai nilai 6,0. Berdasarkan data yang diperoleh menunjukkan bahwa Model Pembelajaran juga merupakan salah satu faktor penting yang mendukung keberhasilan proses pembelajaran di 
dalam kelas. Rusman (2013: 132) Model pembelajaran yang sesuai dan efisien untuk mencapai tujuan pendidikan.

Pada proses belajar pembelajaran dengan menggunakan model pembelajaran Concept Attainmentdalam materi opersi hitung campuran ini pemilihan model yang sangat tepat karena dapat meningkatkan presetasi siswa, hal ini menunjukkan bahwa penerapan model tersebut dalam proses pembelajaran khususnya, pada mata pelajaran Matematika materi operasi hitung campuran, dengan pemahaman konsep yang dimiliki siswa mampu menimba berbagai ilmu pengetahuan. Utomo (2010: 119)Pembelajaran dengan menggunkan model Concept Attainmentini dapat mengembangkan proses befikir. Sehingga dapat memberi dampak positif terhadap siswa, dan dapat menciptakan pembelajaran yang menarik dan bermakana melalui model pemebelajaran Concept Attainment.

\section{KESIMPULAN}

Berdasarkan hasil analisis data tes dan observasi, rata-rata kemampuan pemahaman konsep matematis siswa setelah diterapkan model pembelajaran Concept Attainmentdapat meningkat kan Kemampuan pemahaman konsep matematis siswa.Adapun presentase ketuntasan hasil belajar siswa menunjukkan bahwa pada siklus I sebesar $61.11 \%$ dan meningkat menjadi 83.04\% pada siklus III.

Peningkatan pemahaman konsep pada hasil belajar siswa pada siklus III, menunjukkan antusias siswa dalam pelajaran matematika dengan penerapan model Concept Attainment. PembelajaranConcept Attainment dapat memberikan kesempatan kepada siswa untuk menuangkan gagasan sebelum menjawab permasalahan yang diberikan guru dan mengambangkan pemahaman konsep siswa dalam memahami materi.

\section{REFERENSI}

Aunnurrahman. (2012). Belajar dan Pembelajaran. Bandung: Alfabeta. 
Aqib Zainal, dkk. (2013). Penelitian Tindakan Kelas Untuk Guru SD, SLB, dan TK. Bandung: YramaWidya.

Bruce, Joyce, dkk. (2009). Models of Teaching. Yogyakarta: Pustaka Pelajar.

Hamalik, Oemar. (2008). Kurikulum dan Pembelajaran. Jakarta: Bumi Aksara.

Mulbar, Rsman. (2006). Buletin Pendidikan Matematika. Ambon: FKIP Universitas Pattimura.

Munir. (2016). Kurikulum Berbasis Teknologi Informasi dan Komunikasi. Bandung: Pascasarjana UPI dan CV Alfabeta.

Purwanto Ngalim. (2004). Prinsip-Prinsip dan Tekhnik Evaluasi Pengajaran. Bandung:Remaja Rosdakarya.

Ridwan, (2008). Ketercapaian Prestasi Belajar. Ridwan202.wordpress.com.

Rino Ridwan. Kelabihan Model Concept Attainment, http:/ejournal.unp.ac.id/index.php/pek/article/download/460/260 kelebihan model cencept attainment, 12 November 2014.

Supardan Dadang. (2015). Pembelajaran Presfekstif Dan Kurikulum Pelaksanaan Concept Attainmnet. Bandung: Bumi Aksara. 